\title{
Antioxidant Activities of the Methanol Extracts of Various Parts of Phalaenopsis Orchids with White, Yellow, and Purple Flowers
}

\section{Hoang Chinh NGUYEN ${ }^{\text {la }}$, Kuan-Hung LIN ${ }^{2 b}$, Meng-Yuan HUANG $^{2 *}$, Chi-Ming YANG ${ }^{3}$, Tin-Han SHIH ${ }^{3}$, Tung-Chuan $\mathrm{HSIUNG}^{2}$, Yen-Chang LIN ${ }^{4}$, Fun-Chi TSAO ${ }^{2}$}

\author{
${ }^{1}$ Faculty of Applied Sciences, Ton Duc Thang University, Ho Chi Minh City 700000,Vietnam; nguyenhoangchinh@tdt.edu.vn \\ ${ }^{2}$ Department of Horticulture and Biotechnology, Chinese Culture University, Taipei 114, Taiwan; \\ rlin@faculty.pccu.edu.tw; hmy6@ulive.pccu.edu.tw(*correspondingauthor); bsiungan@faculty.pccu.edu.tw; theresapi@yahoo.com.tw \\ ${ }_{3}^{3 B i o d i v e r s i t y ~ R e s e a r c h ~ C e n t e r, ~ A c a d e m i a ~ S i n i c a, ~ T a i p e i ~ 115, ~ T a i w a n ; ~ c m y a n g @ g a t e . s i n i c a . e d u . t w ; ~ d a m n o s @ g m a i l . c o m ~}$ \\ ${ }^{4}$ Graduate Institute of Biotechnology, Chinese Culture University, Taipei 114, Taiwan; lycnthu@gmail.com \\ ${ }^{a, b}$ These authors contributed equally to this work
}

\begin{abstract}
Phalaenopsis (Phal.) orchids including white, yellow, and purple flowers are some of the most important commercial orchids worldwide. These flowering plants can be considered to be promising sources of antioxidants since several medicinal orchids were shown to have potential antioxidant activities. The antioxidant activities and several secondary metabolite compounds of the methanolic extracts of four parts (the root, pedicel, leaf, and flower) of three hybrids of white (Phal. 'City More'), yellow (Phal. 'Sogo Meili'), and purple (Phal. 'Queen Beer') flowering orchids were investigated. Results showed that the highest levels of chlorophyll $a$ and chlorophyll $b$ were respectively obtained in leaf extracts of white and purple orchids, whereas carotenoid showed the highest content in the flower extract of the yellow orchid. Among all tested extracts, flavonoids and anthocyanin demonstrated the highest levels in the flower extract of the purple orchid, whereas the highest level of polyphenols was observed in the flower extract of the yellow orchid. The leaf extract of the white orchid was the most effective extract with a 50\% inhibitory concentration in the DPPH-scavenging activity assay, while the highest ferrous iron-chelating effect was observed in flower extracts of the yellow orchid and purple orchid, and the pedicel extract of the purple orchid. In the reducing power assay, the flower extract of the white orchid showed the most potent extract, followed by the leaf extract of the yellow orchid and the flower extract of the purple orchid. Relationships between flower colors and antioxidant activities of these orchids showed them to be potential sources of antioxidants for both medicinal use and stress-tolerance in these orchids.
\end{abstract}

Keywords: flowering orchid; natural antioxidants; pigments; plant extract; secondary metabolite compound

\section{Introduction}

The autoxidation process and oxidative stresses cause various problems in human health, such as ageing, cancer, diabetes, and cardiovascular diseases (Sikora et al., 2008; Huang et al., 2016). To address these problems, many synthetic antioxidants have been used worldwide to prevent the autoxidation process and oxidative stress (Prasad et al., 2009). However, the use of such compounds sometimes has adverse side effects on human health (Prasad et al., 2009; Prasad et al., 2010; Brewer, 2011); thus, efforts have been made to replace these conventional antioxidants. As a result, the use of plant products as natural antioxidants in reducing free radical-induced tissue injury has attracted much attention in recent years (Pokorný, 2007; Brewer, 2011). These natural antioxidants have been widely proven to be potential medicines to maintain health, prevent oxidative stress-mediated diseases, and delay ageing processes (Djeridane et al., 2006; Beta et al., 2017; Caleja et al., 2017). Moreover, these antioxidant resources can be used in cosmetics and foods to enhance defense systems (Chen $e t$ al., 2016; Hübner $e t$ al., 2016). Therefore, the search for new and safe antioxidants from natural sources is the objective of continued investigations.

Orchids, rated as the most diverse species of all angiosperm families, comprise over 25,000 species (Zahara et al., 2016), among which, terrestrial, epiphytic, and 
458

saprophytic species are the dominant types of orchids (Rashmi et al., 2015). They are distributed worldwide with various diversities in floral parts such as shape, color, and size of the flower (Rashmi et al., 2015). These orchids play important economic roles since they are widely cultivated for ornamental purposes (Tsai $e t$ al., 2015). In addition, several medicinal orchids have been used as food and traditional medicine as anti-inflammatory (Chinsamy et al., 2014), anti-cholinesterase (Chinsamy et al., 2014), antibacterial (He et al., 2016), and anticancer treatments (Sun et al., 2016). Recently, various plant parts of medicinal orchids such as Anacamptis pyrimidalis (Štajner et al., 2010), Habenaria edgeworthii (Giri et al., 2012), Ansellia africana (Chinsamy et al., 2014), Eulophia petersii (Chinsamy et al., 2014), and Dendrobium nobile (Bhattacharyya et al., 2016), were reported to be potential sources of antioxidants. Various phytochemicals with high biological activity, including carotenoids, flavonoids, phenolics, and their derivatives were found in orchid extracts that showed powerful antioxidant activities (Štajner et al., 2010). The antioxidant activities of these compounds are based on scavenging diverse reactive oxygen species (ROS), including peroxyl radicals, hydroxyl radicals, hypochlorous acid, superoxide anions, and peroxynitrite, thus protecting the human body against oxidative damages (Chao et al., 2014). Orchids are therefore considered to be promising natural sources of antioxidants (Chinsamy et al., 2014).

Phalaenopsis orchids are some of the most important commercial floriculture species in the world because of their beautiful flowers and prolonged blooming (Hsing et al., 2016). These orchids have been increasingly marketed worldwide as cut flowers and potted plants and contribute $70 \%$ to the value of wholesale flowering plant sales (Guo et al., 2012; Zahara et al., 2016). Recently, hybrids with improved characteristics have been developed, and interspecific hybridization has been achieved to produce cultivars with improved flower colors (Tatsuzawa et al., 2010). Many varieties with various flower colors, including white, orange-red, red, pink, and reddish-purple have been developed. Nevertheless, there is limited information about the relationships between flower color and antioxidant activity of these plants. Of those hybrids, the white (Phal. 'City More'), yellow (Phal. 'Sogo Meili'), and purple (Phal. 'Queen Beer') flowering orchids are the most popular orchids (Tsai et al., 2015) and are mostly imported from Thailand and Taiwan (Guo et al., 2012; Zahara et al., 2016). Presently, Taiwan is the leading country for exporting Phalaenopsis orchids and has produced over 80 million Phalaenopsis products from tissue culture (Chen, 2015). However, besides being used for ornamental purposes, these plants can be considered to be promising sources of antioxidants. Although several studies were conducted on medicinal orchids as potential sources of antioxidants (Giri et al., 2012; Chinsamy et al., 2014; Bhattacharyya et al., 2015a), no study has reported the antioxidant capacity among various flower colors of orchid plants. A better understanding of these relationships would aid the effective selection processes of novel flower colors of Phalaenopsis breeding programs in the future. Higher levels of antioxidants would also provide protective mechanisms that allow orchid plants to tolerate stressful environments. The aim of our study was to investigate the antioxidant activities of the methanolic extracts from the root, leaf, pedicel, and flower of three Taiwanese flowering orchids (Phal. 'City More', Phal. 'Sogo Meili', and Phal. 'Queen Beer'). Moreover, levels of chlorophyll, anthocyanin, polyphenols, and total flavonoids in the aforementioned tissues of orchids were also examined.

\section{Materials and Methods}

\section{Plant materials and preparation of plant extracts}

Four parts (the root, pedicel, leaf, and flower) of three hybrids of white (Phal. 'City More'), yellow (Phal. 'Sogo Meili'), and purple (Phal. 'Queen Beer') flowering orchids in 3-inch $(7.6 \mathrm{~cm}$ ) plastic pots were used (Fig. S1). All plants were purchased from a local commercial entity, the Taipei Flower Auction (Neihu District, Taipei City, Taiwan). Pots containing commercial peat moss were placed in a controlled-environment greenhouse under an 8-h photoperiod at $28 / 22{ }^{\circ} \mathrm{C}$ day/night temperatures and a relative humidity of $80 \%$. They were evenly spaced to encourage similar growth rates and sizes. Plants were watered once a week, and an optimal amount of a compound fertilizer solution $\left(\mathrm{N}: \mathrm{P}_{2} \mathrm{O}_{5}: \mathrm{K}_{2} \mathrm{O}, 20: 20: 20\right)$ was applied once every 2 weeks. Plants were maintained for 1 month, and those of a uniform size were then chosen for the antioxidant activity analysis. The experiment was performed twice independently with a randomized design for the growth environment, sampling day, and physiological analyses.

To extract compounds, $0.25 \mathrm{~g}$ of dry powder of each plant part was immersed in $5 \mathrm{ml}$ methanol at room temperature. The liquid phase was then separated from the cell debris through filtration under a vacuum using filter paper (Whatman No. 1) to obtain the crude orchid extract which was used for further experiments.

Determination of chlorophyll, carotenoid, anthocyanin, total flavonoid, and polyphenols

Chlorophyll (Chl) and carotenoid (Car) contents were determined using methods described by Porra et al. (1989). Briefly, $0.01 \mathrm{~g}$ of orchid dry power was mixed with $5 \mathrm{~mL}$ of $80 \%$ acetone at $4{ }^{\circ} \mathrm{C}$ overnight, followed by centrifugation at $13,000 \mathrm{~g}$ for $5 \mathrm{~min}$ to obtain the supernatant. The supernatants were then tested to determine the absorbance of Chl $a$ and $\mathrm{Chl} b$ in acetone at 663.6 and $646.6 \mathrm{~nm}$, respectively, using a Hitachi U-2000 type spectrophotometer (Tokyo, Japan). Concentrations of Chl $a$, Chl $b$, and carotenoid were calculated using the following equations:

$\mathrm{Chl} a=\left(12.25 \times \mathrm{OD}_{663.6}-2.55 \times \mathrm{OD}_{646.6}\right) \times$ volume of supernatant $(\mathrm{ml}) /$ sample weight $(\mathrm{g})$;

Chl $b=\left(20.31 \times \mathrm{OD}_{646.6}-4.91 \times \mathrm{OD}_{663.6}\right) \times$ volume of supernatant $(\mathrm{ml}) /$ sample weight $(\mathrm{g})$;

Car $=\left[\left(4.69 \times \mathrm{OD}_{440.5} \times\right.\right.$ volume of supernatant $(\mathrm{ml}) /$ sample weight $(\mathrm{g})]-0.267 \times(\mathrm{Chl} a+\mathrm{Chl} b)$.

Anthocyanin contents of the extracts were measured based on the protocol of Mancinelli et al. (1975). A mixture 
of $99 \%$ methanol containing $1 \% \mathrm{HCl}$ was added to powder samples and incubated for $1 \mathrm{~h}$ at room temperature. The mixture was then centrifuged at $4{ }^{\circ} \mathrm{C}$ and $3000 \mathrm{rpm}$ for 5 min to obtain the supernatant. The supernatant was then used to measure absorbances at 530 and $657 \mathrm{~nm}$ on a spectrophotometer. The following equation was used:

Anthocyanin content $\left(\mu \mathrm{mol} . \mathrm{g}^{-1} \mathrm{DW}\right)=\left(\mathrm{A}_{530}-0.33 \times\right.$ $\left.\mathrm{A}_{657} / 31.6\right) \times$ volume of supernatant $(\mathrm{ml}) /$ sample weight (g).

Total flavonoids in the orchid extracts were determined by the method of Djeridane et al. (2006). One milliliter of methanol extract $\left(0.5 \mathrm{mg} \cdot \mathrm{ml}^{-1}\right)$ was mixed with $1 \mathrm{ml}$ aluminum chloride (2\%). The mixture was stirred and kept at room temperature for $15 \mathrm{~min}$. The absorbance was measured at $430 \mathrm{~nm}$ using a spectrophotometer. Quercetin was used as a reference standard, and the total flavonoid content was expressed as milligrams of quercetin equivalents per gram of dry weight (mg QE.g. $\left.{ }^{-1} \mathrm{DW}\right)$.

Polyphenol content was determined according to the method of Taga et al. (1984). Briefly, standard gallic acid and an aliquot of the acidic methanolic extract were diluted with acidified methanol solution containing $1 \% \mathrm{HCl}$. Two $\mathrm{ml}$ of $2 \% \mathrm{Na}_{2} \mathrm{CO}_{3}$ were mixed into each sample of $100 \mu \mathrm{l}$ and allowed to equilibrate for $2 \mathrm{~min}$ before adding $50 \%$ Folin-Ciocalteu reagent. Absorbance at $750 \mathrm{~nm}$ was measured at room temperature using the Varioskan Flash Multimode Reader (Thermo Scientific, Rockford, IL, USA). The standard curve for gallic acid was used to calculate polyphenol levels. Total phenolics were expressed as the mg gallic acid equivalent (GAE). $\mathrm{g}^{-1}$ of dry weight. The standard curve equation was $y=0.4995 x-0.011$, where $R^{2}$ $=0.9944$.

\section{Determination of the Antioxidant Activity \\ 2,2-Diphenyl-1-picrylhydrazyl (DPPH) \\ radical-} scavenging activity assay

DPPH free radical-scavenging activities of the orchid extracts were determined according to the method of Yoshiki et al. (2001) with slight modifications. Aliquots of serial dilutions of $0.05 \mathrm{ml}$ of the methanol extract were added to $0.15 \mathrm{ml}$ of a DPPH solution $(0.4 \mathrm{mM}$ in methanol). The mixture was then well mixed and left at room temperature for $90 \mathrm{~min}$ in the dark before measuring the absorbance at $517 \mathrm{~nm}$ using a Hitachi U-2000 type spectrophotometer. The radical-scavenging activity was calculated using the following equation:

Scavenging activity $(\%)=\left[1-\left(\mathrm{OD}_{1}\right.\right.$ sample $-\mathrm{OD}_{2}$ sample) / ( $\mathrm{OD}_{3}$ control - OD 4 control $\left.)\right] \times 100 \%$.

Methanol was used instead of a sample as the control. The $\mathrm{OD}_{1}$ sample contained added DPPH in the experimental group, but the $\mathrm{OD}_{2}$ sample did not contain added DPPH in the experimental group. The $\mathrm{OD}_{3}$ control contained added DPPH in the control (methanol), whereas the $\mathrm{OD}_{4}$ control did not contain added $\mathrm{DPPH}$ in the control (methanol). A calibration curve was constructed using different concentrations $(10 \sim 100 \mu \mathrm{M})$ of butylated hydroxytoluene (BHT) as a positive control. The concentration required for a $50 \%$ decrease in the absorbance of DPPH radicals $\left(\mathrm{IC}_{50}\right)$ was then calculated as the percent inhibition of DPPH by plotting the percentage of residual $\mathrm{DPPH}$ at a steady state as a function of the sample extract concentration.

\section{Determination of the ferrous iron-chelating ability}

The ferrous iron-chelating ability was determined based on the method of Dinis et al. (1994). Briefly, an aliquot of 1 $\mathrm{ml}$ of the methanol extract was added to $3.7 \mathrm{ml}$ of $80 \%$ methanol containing $100 \mu \mathrm{l}$ of $2 \mathrm{mM} \mathrm{FeCl}_{2} \cdot 4 \mathrm{H}_{2} \mathrm{O}$. The mixture was allowed to sit for $30 \mathrm{~s}$, followed by the addition of $200 \mu \mathrm{l}$ of a $5 \mathrm{mM}$ ferrozine solution, and then incubated for $10 \mathrm{~min}$ at room temperature before the absorbance was measured at $562 \mathrm{~nm}$. The ferrous iron-chelating ability was calculated as follows:

Ferrous iron-chelating ability $(\%)=\left[1-\left(\mathrm{OD}_{1}\right.\right.$ sample $\mathrm{OD}_{2}$ sample $) /\left(\mathrm{OD}_{3}\right.$ control - OD 4 control $\left.)\right] \times 100 \%$.

Methanol was used instead of a sample as the control. The $\mathrm{OD}_{1}$ sample contained added DPPH in the experimental group, but the $\mathrm{OD}_{2}$ sample did not contain added DPPH in the experimental group. The $\mathrm{OD}_{3}$ control contained added DPPH in the control (methanol), whereas the $\mathrm{OD}_{4}$ control did not contain added DPPH in the control (methanol). A standard curve was made using $10 \sim 100 \mu \mathrm{M}$ ethylenediaminetetraacetic acid (EDTA) as a positive control. The concentration required for a $50 \%$ decrease in the absorbance of ferrous iron $\left(\mathrm{IC}_{50}\right)$ was calculated as the percent inhibition of ferrous iron by plotting the percentage of residual ferrous iron in a steady state as a function of the sample extract concentration.

\section{Measurement of the reducing power}

The reducing power of the extracts was determined as described by Pulido et al. (2000). A sample extract (100 mg) in $2 \mathrm{ml}$ methanol was mixed with phosphate buffer $(50 \mu \mathrm{l}$, $0.2 \mathrm{M}, \mathrm{pH}$ 6.6) and potassium ferricyanide (50 $\mu \mathrm{l}, 1 \%)$ and the mixture was incubated at $50{ }^{\circ} \mathrm{C}$ for $20 \mathrm{~min}$. Trichloroacetic acid $(50 \mu \mathrm{l}, 10 \%)$ was added to the reaction mixture, which was then centrifuged at $3000 \mathrm{rpm}$ for 10 min. The supernatant $(90.9 \mu \mathrm{l})$ was mixed with an equal volume of distilled-deionized water (d.d. $\mathrm{H}_{2} \mathrm{O}$ ) and $18.2 \mu \mathrm{l}$ of $0.1 \%$ ferric chloride. After $10 \mathrm{~min}$, the absorbance at 700 nm was measured against a blank. The reduction capacity was calculated as follows:

Reduction capacity $(\%)=[(\mathrm{OD}$ sample - OD control $) /$ OD standard] $\times 100 \%$.

Methanol was used instead of a sample as the control, and BHT in methanol was used as the standard. The concentration required for a $50 \%$ decrease in the absorbance of the reducing power $\left(\mathrm{IC}_{50}\right)$ was then calculated as the percent inhibition of the reducing power by plotting the percentage of the residual reducing power in a steady state as a function of the sample extract concentration.

\section{Statistical analysis}

Data were determined in triplicate, and results are expressed as the mean \pm standard deviation (SD). An analysis of variance (ANOVA) with the least significant difference (LSD) test at $p \leq 0.05$ was performed using SAS vers. 9 (SAS Institute, Cary, NC, USA).

\section{Results}

Photosynthesis pigments and secondary metabolite compounds among orchid extracts

Table 1 presents the contents of $\mathrm{Chl} a, \mathrm{Chl} b, \mathrm{Chl} a+b$, 
460

Chl $a / b$, carotenoids, flavonoids, polypenols, and anthocyanin in extracts of different parts of the orchids. Results show that in all orchid species tested, levels of $\mathrm{Chl} a$, $\mathrm{Chl} b$, total $\mathrm{Chl}$, and carotenoids in leaves were significantly higher than those of other plant parts in each plant, while the flowers contained a higher ratio of $\mathrm{Chl} a / b$ compared to other parts due to the Chl $b$ lower contents. Of those orchid extracts tested, the highest contents of Chl $a(2.19 \pm 0.42$ $\left.\mathrm{mg} . \mathrm{g}^{-1} \mathrm{DW}\right)$ and $\mathrm{Chl} b\left(1.06 \pm 0.31 \mathrm{mg} \cdot \mathrm{g}^{-1} \mathrm{DW}\right)$ were obtained in leaf extracts of white and purple orchids, respectively, whereas carotenoid reached the highest level $\left(0.82 \pm 0.02 \mathrm{mg.g}^{-1} \mathrm{DW}\right)$ in the methanolic flower extract of the yellow orchid. In addition, among all examined samples, the highest flavonoid and anthocyanin contents were found in the flower extract of the purple orchid at $138.70 \pm 3.03$ $\mathrm{mg} \mathrm{QE.g} \mathrm{g}^{-1} \mathrm{DW}$ and $147.48 \pm 11.85 \mu \mathrm{g} \cdot \mathrm{g}^{-1} \mathrm{DW}$, respectively. However, the flower extract of the white orchid had low flavonoid $\left(8.10 \pm 1.06 \mathrm{mg} \mathrm{QE.} \mathrm{g}^{-1} \mathrm{DW}\right)$ and anthocyanin $\left(12.01 \pm 4.71 \mu \mathrm{mol} . \mathrm{g}^{-1} \mathrm{DW}\right)$ contents compared to other parts. Leaf extracts of the yellow orchid contained significantly higher flavonoid $\left(51.59 \pm 8.05 \mathrm{mg} \mathrm{QE.g}{ }^{-1}\right.$ DW) and anthocyanin (40.57 $\pm 3.73 \mu$ mol.g ${ }^{-1}$ DW) contents than the other parts. Flower $(446.22 \pm 60.03 \mathrm{mg}$ gallic acid. $\left.\mathrm{g}^{-1} \mathrm{DW}\right)$ and leaf $(244.23 \pm 51.39 \mathrm{mg}$ gallic acid.g ${ }^{\mathrm{D}} \mathrm{DW}$ ) of yellow plant contained significantly higher levels of polyphenols compared to other plants.

\section{Antioxidant activities among the orchid extracts}

The antioxidant activities of orchid extracts were measured as DPPH radical-scavenging activity, the ferrous iron-chelating ability, and a ferric-reducing power assay. As shown in Fig. 1, different parts of the orchid plants possessed different free radical-scavenging activities. Leaf extracts of white and yellow orchids had significant higher
DPPH radical scavenging activities $\left(5 \sim 25 \mathrm{mg}^{-\mathrm{ml}^{-1}}\right)$ than other parts in each species. However, in the purple orchid, significantly lower radical-scavenging activity $\left(1 \sim 50 \mathrm{mg} \cdot \mathrm{ml}^{-}\right.$ $\left.{ }^{1}\right)$ was observed in the pedicel extract. Furthermore, among the three species tested, the leaf extract of the white orchid was the most potent extract with an $\mathrm{IC}_{50}$ of $8.01 \pm 0.97$ $\mathrm{mg} \cdot \mathrm{ml}^{-1}$, followed by the yellow orchid $\left(\mathrm{IC}_{50}=12.73 \pm 0.37\right.$ mg.ml ${ }^{-1}$ ) (Table 2). Compared to white and yellow orchids, all parts of the purple orchid demonstrated a lower ability to scavenge DPPH with $\mathrm{IC}_{50}$ values of $16.91 \pm 3.54 \sim 32.63 \pm$ $1.84 \mathrm{mg} \cdot \mathrm{ml}^{-1}$.

Fig. 2 shows that the ferrous iron-chelating effect significantly differed among orchid extracts. The flower extracts of white and yellow species displayed significantly higher iron-chelating rates $\left(5 \sim 10 \mathrm{mg}^{-\mathrm{ml}^{-1}}\right)$ than other parts. Moreover, both the flower and pedicel extracts of the purple species exhibited significantly higher iron-chelating rates $\left(1 \sim 10 \mathrm{mg} \cdot \mathrm{ml}^{-1}\right)$ than those of the leaves and roots. The highest ferrous iron-chelating effect was observed in flower extracts of the yellow orchid $\left(\mathrm{IC}_{50}=1.02 \pm 0.27 \mathrm{mg} \cdot \mathrm{ml}^{-1}\right)$ and purple orchid $\left(\mathrm{IC}_{50}=1.50 \pm 0.23 \mathrm{mg} \mathrm{ml}^{-1}\right)$, and the pedicel extract of the purple orchid ( $\mathrm{IC}_{50}$ of $1.71 \pm 0.33$ mg. $\mathrm{ml}^{-1}$ ) (Table 2).

Fig. 3 demonstrates various levels of reducing powers in different plant parts. Both the flower and leaf extracts of white and yellow species exhibited higher reducing power activities $\left(5 \sim 50 \mathrm{mg} \cdot \mathrm{ml}^{-1}\right)$ than the root and pedicel in each plant, whereas the flower extract of the purple orchid showed higher reducing power activity $\left(5 \sim 50 \mathrm{mg} \cdot \mathrm{ml}^{-1}\right)$ than the other parts. Of all samples tested, the flower extract of the white orchid was the most effective in reducing activity with an $\mathrm{IC}_{50}$ of $15.02 \pm 1.12 \mathrm{mg} \cdot \mathrm{ml}^{-1}$, followed by the leaf extract of the yellow orchid $\left(\mathrm{IC}_{50}=20.46 \pm 0.98 \mathrm{mg} \cdot \mathrm{ml}^{-1}\right.$ ) and the flower extract of the purple orchid $\left(\mathrm{IC}_{50}=23.53 \pm\right.$ $\left.1.02 \mathrm{mg} \cdot \mathrm{ml}^{-1}\right)$.

Table 1. Content of pigments, flavonoids, polyphenol, and anthocyanin in extracts of different parts of orchids

\begin{tabular}{|c|c|c|c|c|c|c|c|c|c|}
\hline Species & Part & $\begin{array}{c}\mathrm{Chl} a \\
\left(\mathrm{mg} \cdot \mathrm{g}^{-1} \mathrm{DW}\right)\end{array}$ & $\begin{array}{c}\mathrm{Chl} b \\
\left(\mathrm{mg} \cdot \mathrm{g}^{-1} \mathrm{DW}\right)\end{array}$ & $\begin{array}{c}\mathrm{Chl} a+b \\
\left(\mathrm{mg} \cdot \mathrm{g}^{-1} \mathrm{DW}\right)\end{array}$ & $\mathrm{Chl} a / b$ & $\begin{array}{c}\text { Car } \\
\left(\mathrm{mg} \cdot \mathrm{g}^{-1} \mathrm{DW}\right)\end{array}$ & $\begin{array}{c}\text { Fla } \\
\left(\mathrm{mg} \mathrm{QE} \cdot \mathrm{g}^{-1}\right. \\
\text { DW) }\end{array}$ & $\begin{array}{c}\text { Pph } \\
\left(\mathrm{mg} \mathrm{GAE} \cdot \mathrm{g}^{-1}\right. \\
\text { DW) }\end{array}$ & $\begin{array}{c}\text { Ant } \\
\left(\mu \mathrm{mol} . \mathrm{g}^{-1} \mathrm{DW}\right)\end{array}$ \\
\hline \multirow{4}{*}{$\begin{array}{l}\text { Phal. } \\
\text { 'City } \\
\text { More' }\end{array}$} & Root & $0.56 \pm 0.08 c$ & $0.27 \pm 0.05 c$ & $0.83 \pm 0.13 \mathrm{~d}$ & $2.07 \pm 0.11 b c$ & $0.32 \pm 0.06 \mathrm{e}$ & $17.54 \pm 4.00 \mathrm{ef}$ & $115.96 \pm 13.17 \mathrm{de}$ & $13.19 \pm 2.81 \mathrm{ef}$ \\
\hline & Pedicle & $0.51 \pm 0.09 \mathrm{c}$ & $0.23 \pm 0.04 \mathrm{c}$ & $0.74 \pm 0.13 \mathrm{~d}$ & $2.29 \pm 0.11 b$ & $0.23 \pm 0.05 f$ & $29.17 \pm 3.43 c$ & $89.85 \pm 8.43 \mathrm{e}$ & $30.05 \pm 5.07 \mathrm{c}$ \\
\hline & Leaf & $2.19 \pm 0.42 \mathrm{a}$ & $0.96 \pm 0.21 \mathrm{a}$ & $3.15 \pm 0.63 a$ & $2.28 \pm 0.06 b$ & $0.79 \pm 0.10 \mathrm{ab}$ & $49.12 \pm 6.35 b$ & $92.75 \pm 9.54 \mathrm{e}$ & $32.60 \pm 6.32 c$ \\
\hline & Flower & $0.07 \pm 0.02 \mathrm{e}$ & $0.02 \pm 0.01 \mathrm{~d}$ & $0.09 \pm 0.03 f$ & $3.14 \pm 0.87 \mathrm{a}$ & $0.14 \pm 0.23 \mathrm{~g}$ & $8.10 \pm 1.06 \mathrm{~g}$ & $110.48 \pm 16.68 \mathrm{de}$ & $12.01 \pm 4.71 \mathrm{ef}$ \\
\hline \multirow{4}{*}{$\begin{array}{l}\text { Phal. } \\
\text { 'Sogo } \\
\text { Meili' }\end{array}$} & Root & $0.42 \pm 0.10 \mathrm{~cd}$ & $0.23 \pm 0.05 c$ & $0.64 \pm 0.15 \mathrm{de}$ & $1.84 \pm 0.08 c$ & $0.39 \pm 0.07 \mathrm{de}$ & $32.91 \pm 7.57 c$ & $118.48 \pm 31.42 \mathrm{de}$ & $23.16 \pm 5.39 d$ \\
\hline & Pedicle & $0.53 \pm 0.07 \mathrm{c}$ & $0.27 \pm 0.04 c$ & $0.80 \pm 0.11 \mathrm{~d}$ & $2.01 \pm 0.07 \mathrm{bc}$ & $0.24 \pm 0.03 f$ & $12.82 \pm 0.29 f$ & $153.43 \pm 30.91 \mathrm{~cd}$ & $16.71 \pm 2.52 \mathrm{ef}$ \\
\hline & Leaf & $1.80 \pm 0.08 b$ & $0.91 \pm 0.05 a$ & $2.71 \pm 0.13 b$ & $1.99 \pm 0.04 \mathrm{bc}$ & $0.78 \pm 0.02 \mathrm{ab}$ & $51.59 \pm 8.05 b$ & $244.23 \pm 51.39 b$ & $40.57 \pm 3.73 b$ \\
\hline & Flower & $0.25 \pm 0.01 \mathrm{de}$ & $0.12 \pm 0.03 c d$ & $0.37 \pm 0.04 \mathrm{ef}$ & $2.23 \pm 0.34 b$ & $0.82 \pm 0.02 \mathrm{a}$ & $21.62 \pm 3.58 \mathrm{de}$ & $446.22 \pm 60.03 a$ & $14.45 \pm 3.07 \mathrm{ef}$ \\
\hline Phal. & Root & $0.15 \pm 0.03 e$ & $0.44 \pm 0.09 b$ & $0.59 \pm 0.12 \mathrm{de}$ & $0.34 \pm 0.02 \mathrm{e}$ & $0.5 \pm 0.06 c$ & $15.40 \pm 2.37 \mathrm{ef}$ & $115.00 \pm 22.92 \mathrm{de}$ & $7.26 \pm 0.68 \mathrm{~g}$ \\
\hline 'Quee & Pedicle & $0.15 \pm 0.05 \mathrm{e}$ & $0.48 \pm 0.16 b$ & $0.63 \pm 0.20 \mathrm{de}$ & $0.30 \pm 0.01 \mathrm{e}$ & $0.38 \pm 0.04 \mathrm{e}$ & $25.88 \pm 2.52 \mathrm{~cd}$ & $78.24 \pm 11.28 \mathrm{e}$ & $16.61 \pm 1.26 \mathrm{ef}$ \\
\hline $\mathrm{n}$ & Leaf & $0.26 \pm 0.05 d$ & $1.06 \pm 0.31 \mathrm{a}$ & $1.31 \pm 0.35 c$ & $0.25 \pm 0.02 \mathrm{e}$ & $0.46 \pm 0.02 \mathrm{~cd}$ & $32.02 \pm 6.41 c$ & $124.67 \pm 16.41 \mathrm{de}$ & $19.83 \pm 1.77 \mathrm{de}$ \\
\hline Beer' & Flower & $0.05 \pm 0.01 \mathrm{e}$ & $0.11 \pm 0.02 \mathrm{~cd}$ & $0.16 \pm 0.03 f$ & $0.52 \pm 0.11 \mathrm{~d}$ & $0.22 \pm 0.04 \mathrm{f}$ & $138.70 \pm 3.03 a$ & $179.61 \pm 43.75 c$ & $147.48 \pm 11.85 a$ \\
\hline
\end{tabular}

All values are the mean \pm SD $(n=3 \sim 5)$. Means within a column with different letters significantly differ by Duncan's test at $p<0.05$.

Table 2. The 50\% inhibitory concentration (IC50) values of DPPH radical-scavenging activities, ferrous iron-chelating abilities, and ferric-reducing power assay of extracts of different parts of orchids

\begin{tabular}{|c|c|c|c|c|}
\hline Species & Part & DPPH scavenge $\left(\mathrm{mg} \cdot \mathrm{ml}^{-1}\right)$ & $\mathrm{Fe}^{2+}$-chelating effect $\left(\mathrm{mg} \cdot \mathrm{ml}^{-1}\right)$ & Reducing power rate $\left(\mathrm{mg} \cdot \mathrm{ml}^{-1}\right)$ \\
\hline \multirow{4}{*}{ Phal. 'City More' } & Root & $18.20 \pm 0.78 \mathrm{~cd}$ & $6.60 \pm 0.79 \mathrm{~cd}$ & $34.29 \pm 3.60 b c$ \\
\hline & Pedicel & $15.13 \pm 1.57 \mathrm{de}$ & $35.88 \pm 5.58 \mathrm{a}$ & $44.04 \pm 8.45 a$ \\
\hline & Leaf & $8.01 \pm 0.97 \mathrm{~g}$ & $3.44 \pm 0.38 \mathrm{~d}$ & $27.42 \pm 2.34 \mathrm{c}$ \\
\hline & Flower & $15.51 \pm 1.22 \mathrm{de}$ & $3.25 \pm 0.22 \mathrm{~d}$ & $15.02 \pm 1.12 f$ \\
\hline
\end{tabular}




\begin{tabular}{ccccc}
\hline & Root & $17.86 \pm 0.83 \mathrm{~d}$ & $7.51 \pm 0.47 \mathrm{c}$ & $36.25 \pm 1.24 \mathrm{~b}$ \\
\multirow{2}{*}{ Phal. 'Sogo Meili' } & Pedicel & $30.42 \pm 3.66 \mathrm{a}$ & $3.40 \pm 0.58 \mathrm{~d}$ & $44.48 \pm 8.10 \mathrm{a}$ \\
& Leaf & $12.73 \pm 0.37 \mathrm{f}$ & $24.40 \pm 5.56 \mathrm{~b}$ & $20.46 \pm 0.98 \mathrm{e}$ \\
& Flower & $14.79 \pm 0.38 \mathrm{e}$ & $1.02 \pm 0.27 \mathrm{e}$ & $33.66 \pm 5.64 \mathrm{bc}$ \\
\hline \multirow{2}{*}{ Phal. 'Queen Beer' } & Root & $19.66 \pm 0.73 \mathrm{~cd}$ & $5.81 \pm 0.25 \mathrm{~cd}$ & $33.74 \pm 4.13 \mathrm{bc}$ \\
& Pedicel & $32.63 \pm 1.84 \mathrm{a}$ & $1.71 \pm 0.33 \mathrm{e}$ & $37.31 \pm 6.69 \mathrm{~b}$ \\
& Leaf & $21.24 \pm 1.52 \mathrm{~b}$ & $5.73 \pm 0.86 \mathrm{~cd}$ & $31.32 \pm 1.73 \mathrm{bc}$ \\
\hline \multirow{2}{*}{ Standard $\left(\mu \mathrm{g} \cdot \mathrm{ml}^{-1}\right)$} & Flower & $16.91 \pm 3.54 \mathrm{de}$ & $1.50 \pm 0.23 \mathrm{e}$ & $23.53 \pm 1.02 \mathrm{~d}$ \\
\hline All values are the mean $\pm \mathrm{SD}(n=3 \sim 5)$. Means within a column with different letters significantly differ by Duncan's test at $p<0.05$. & $3.76 \pm 0.18$ \\
\hline
\end{tabular}
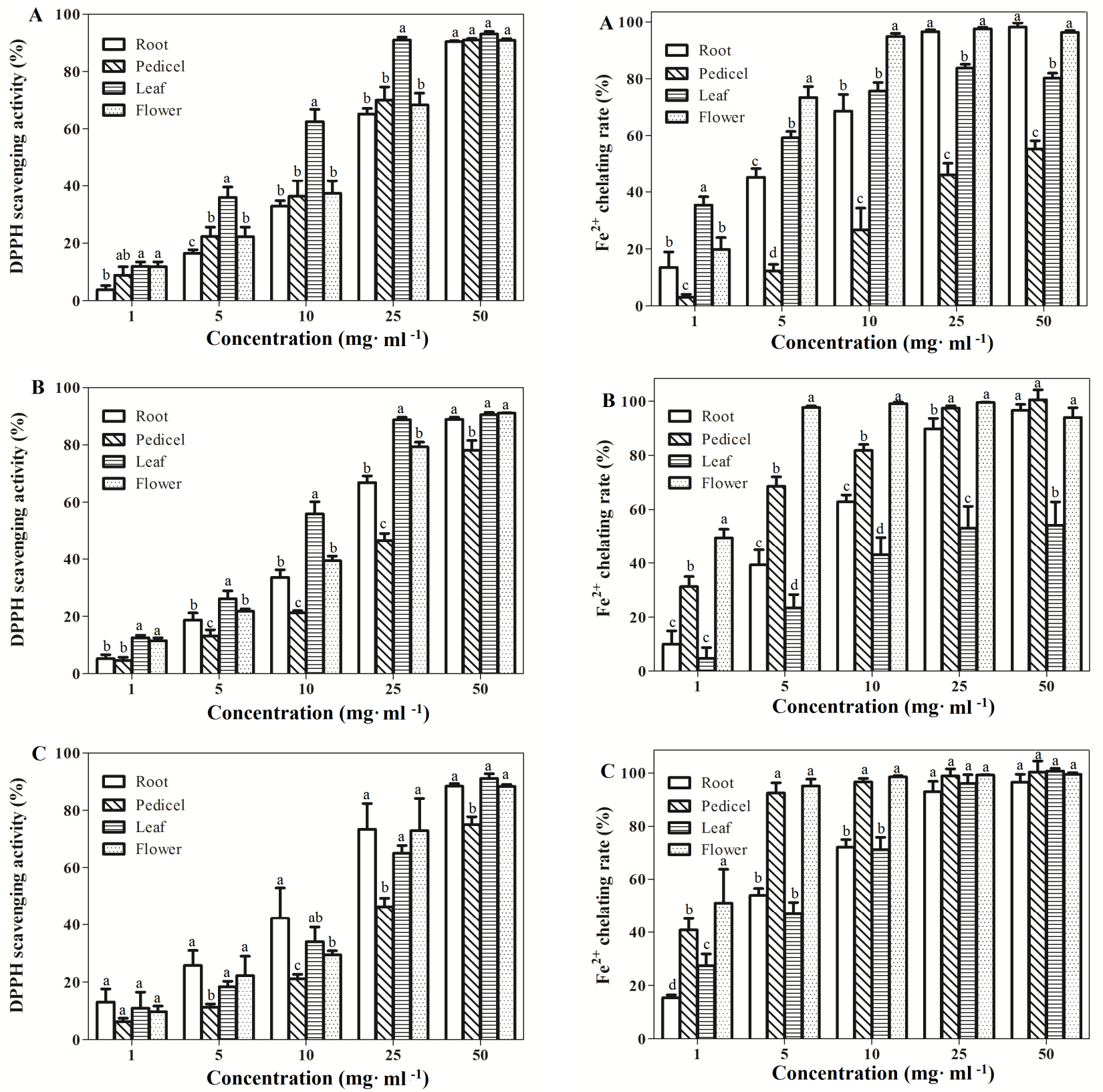

Fig. 1. DPPH-scavenging activities of white (Phal. 'City More', Panel A), yellow (Phal. 'Sogo Meili', Panel B), and purple (Phal. 'Queen Beer', Panel C) orchid extracts. Vertical bars indicate the standard deviation $(n=5)$, a, b, and $c$ : different characters represent significant difference by Duncan's test at $\mathrm{p}<0.05$

Fig. 2. $\mathrm{Fe}^{2+}$-chelating abilities of white (Phal. 'City More', Panel A), yellow (Phal. 'Sogo Meili', Panel B), and purple (Phal. 'Queen Beer', Panel C) orchid extracts. Vertical bars indicate the standard deviation $(\mathrm{n}=5)$. a, b, c and d: different characters represent significant difference by Duncan's test at $\mathrm{p}$ $<0.05$ 
462
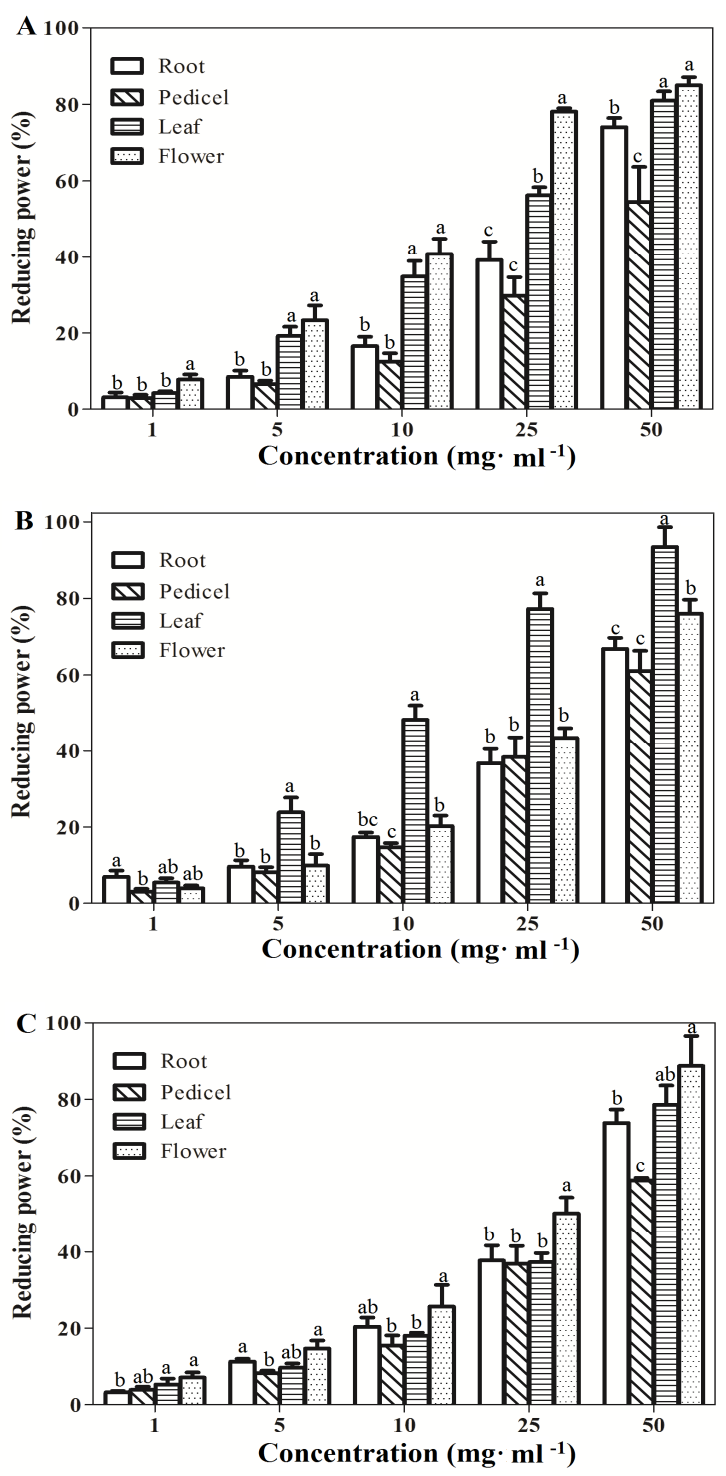

Fig. 3. Reducing power activities of white (Phal. 'City More', Panel A), yellow (Phal. 'Sogo Meili', Panel B), and purple (Phal. 'Queen Beer', Panel C) orchid extracts. Vertical bars indicate the standard deviation $(n=5)$. $a, b$, and $c$ : different characters represent significant difference by Duncan's test at $\mathrm{p}<0.05$

\section{Discussion}

The Orchidaceae is one of the largest families of flowering plants, and many of its members have been developed worldwide for market use. Several medicinal orchid species were found to contain many phytochemicals, such as phenols, terpenoids, flavonoids, alkaloids, and steroids in either plant parts or the entire plants (Štajner $e t$ al., 2010; Bhattacharyya et al., 2015b). In our study, different plant parts of three Taiwanese orchid hybrids displayed wide variations in photosynthetic pigments, flavonoids, polyphenols, and anthocyanin contents as well as antioxidant activities. In general, leaves of all tested orchids were rich in $\mathrm{Chl} a$ and $b$, and carotenoids, indicating that light is necessary for the synthesis of pigments. White orchid leaves contained more $\mathrm{Chl} a$, Chl $b$, carotenoids, flavonoids, and anthocyanin levels than other tested parts. Yellow orchid leaves also had similar trends except for carotenoid. Both flower and leaf of yellow orchid were abundant in polyphenols Purple orchid flowers contained higher flavonoids and anthocyanin compared to other parts. On the other hand, all flowers showed a higher $\mathrm{Chl} a / b$ ratio than other parts, because significantly low Chl $b$ contents were observed in these flowers. Differences in pigment contents of plant parts might be due to light absorption affecting pigment synthesis, thus causing lower $\mathrm{Chl} a$ and $b$ in roots, flowers, and pedicels compared to leaves. High contents of pigments in leaves of these orchid hybrids could be attributed to the wide existence of those hybrids even under high light and radiation conditions of the environment, since those compounds were reported to play important roles against stressful conditions (de la RosaManzano et al., 2015). A better understanding of the relationships of flower colors with pigment, flavonoid, polyphenols, and anthocyanin contents will stimulate moreefficient breeding of these genera. Further analyses of more pigments and secondary metabolite compounds in other orchid genera may contribute to progress in chemotaxonomic and phylogenic studies in the Orchidaceae.

There has been increasing interest in using antioxidants from plants as functional foods and nutraceutical products with antioxidant properties (Brewer, 2011). Various species
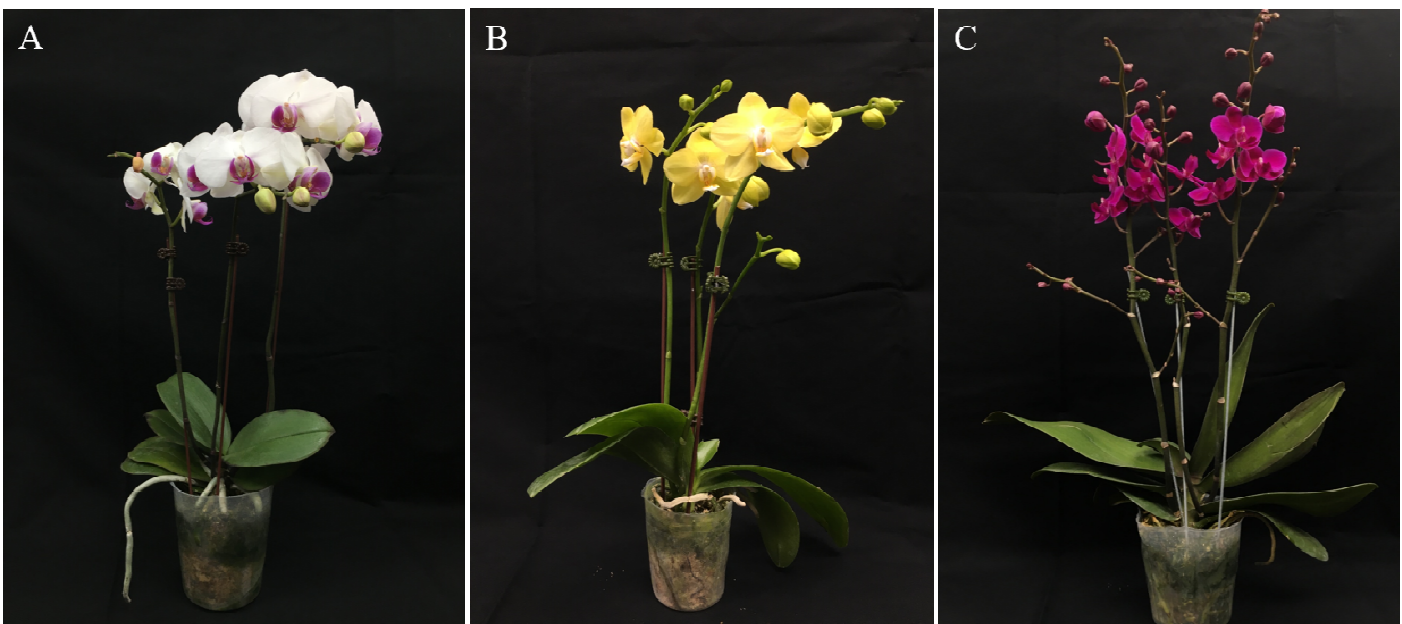

Fig. S1. White (Phal. 'City More', Panel A), yellow (Phal. 'Sogo Meili', Panel B), and purple (Phal. 'Queen Beer', Panel C) orchids were used as plant materials 
of orchids were recently reported to be sources of antioxidants (Chinsamy et al., 2014; Schuster et al., 2017). In this study, the antioxidant activities of different plant parts of three orchid species were studied using DPPHscavenging activity assays since free radical scavenging is one of the mechanisms by which antioxidants inhibit lipid oxidation and prevent oxidative damage (Huang et al., 2017). Flower extracts of the white and yellow species provided significantly higher iron-chelating rates to prevent the formation of ferrozine from ferrous ions than other parts, indicating that those flower extracts were excellent chelators of ferrous ions. The white orchid leaf extract showed the highest $\mathrm{IC}_{50}$ value of DPPH-scavenging activity, while flower extracts of the yellow and purple orchids were the best chelators of ferrous ions in terms of $\mathrm{IC}_{50}$ values of the ferrous iron-chelating ability assay. Alternatively, the flower extract of the white orchid was most potent in terms of the $\mathrm{IC}_{50}$ of the reducing power assay.

Among all samples tested, flower and leaf extracts possessed higher antioxidant activities than pedicel and root extracts within each species. These flowers and leaves contained higher levels of flavonoids and anthocyanin than those of roots and pedicels, since flavonoids and anthocyanin mainly contribute to antioxidant activities (Chao et al., 2014; Bhattacharyya et al., 2016). The presence of the highest flavonoids and anthocyanin in the flower extract of the purple orchid could have played a role in the antioxidant activity observed in the ferrous iron-chelating ability assay. Unlike the DPPH-scavenging activity, the purple orchid was observed to exhibit higher antioxidant activity in the ferrous iron-chelating assay than did the yellow and white orchids, indicating that different extracts have different antioxidant mechanisms. The pedicel and root extracts of all species exhibited lower reducing power activities than extracts from other parts in each plant, indicating that the pedicles and roots have low efficiency in antioxidant activities compared to other plant parts. This might be due to low light absorption in roots and pedicels. The light that plants receive often exceeds the amount needed for photosynthesis, and excess light may cause foliar damage because it increases the probability of the formation of highly oxidizing radicals as ROS (Ledford and Niyogi, 2005). To counteract the formation of these compounds, plant tissues possess different photoprotective mechanisms to remove excess energy or to avoid excess heat, which include leaf and chloroplast movements, carotenoid production, photosystem II heat dissipation of absorbed energy, and heat flux by conduction and convection (Takahashi and Badger, 2011), which reduce the probability of damage to the photosynthetic apparatus. The photoprotective mechanisms may allow orchids to survive in these environments. It is worth investigating how root and foliar concentrations of antioxidants change in different orchid species in response to light intensity changes, and develop different strategies to cope with common environmental challenges for orchids.

The use of orchids as traditional medicines for treating various diseases, such as stomach ache, body ache, headache, fever, and cardiac and nervous disorders was found in Asia, the Americas, Africa, and Europe (Bulpitt, 2005; Pant, 2013). Although many studies on bioactive compounds and pharmaceutical properties of orchids have been conducted, most of that work focused on leaves and stems of medicinal orchid species. This study investigated the pigments and several phytochemicals in various parts of orchids as well as their activities. Our results demonstrated that the flavonoid and anthocyanin contents in tested orchids are much higher than those of many Taiwanese vegetables, including sweet potato (Ipomoea batatas L.), Abelmoschus esculentus Moench, Anisogonium esculentum, Toona sinensis, Asplenium antiquum Makino, Saccharum officinarum, Hemerocallis fulva-green, Nymphoides cristata, Sechium edule, Sechium edule, and Momordica charantia (Huang et al., 2006; Chao et al., 2014). In addition, the antioxidant activity of tested orchids is also comparable to that of sweet potato (Huang et al., 2006; Rumbaoa et al., 2009). The highest total flavonoid values reported in the USDA database (2010) for raw vegetables are capers (Capparis, $\left.28.99 \mathrm{mg} \cdot \mathrm{g}^{-1} \mathrm{DW}\right)$, parsley (11.85 $\left.\mathrm{mg}^{-\mathrm{g}^{-1}} \mathrm{DW}\right)$, lovage (Levisticum officinale, $17.7 \mathrm{mg} . \mathrm{g}^{-1} \mathrm{DW}$ ), dill weed (Anethum graveolens, $6.12 \mathrm{mg} . \mathrm{g}^{-1} \mathrm{DW}$ ), and dock (Rumex spp., 5.10 mg. $\left.\mathrm{g}^{-1} \mathrm{DW}\right)$. From the findings of this study, orchid plants after production of commercial flowers are suggested to be used for health food and medicinal purposes due to their bioactive compounds and antioxidant activities.

\section{Conclusions}

Orchids have been grown worldwide and play important economic roles. Three flowering orchids, Phal. 'City More', Phal. 'Sogo Meili', and Phal. 'Queen Beer', showed potential antioxidant activities due to their high contents of carotenoids, flavonoids, and anthocyanin. The results provide a new direction in the use of flowering orchids as low-cost antioxidant sources, and orchids could be promising materials for the pharmaceutical and neutraceutical industries.

\section{Acknowledgements}

This work was supported by the Shi Fang Yuan Inc. We also would like to thank Prof. Dr. Wen-Huei Chen, Senior Research Fellow, from Orchid Research and Development Center at National Cheng Kung University, Tainan, Taiwan, for reviewing the paper and providing valuable comments regarding to this research. In addition, we also sincerely appreciate.

\section{References}

Beta T, Nam S, Dexter JE, Sapirstein HD (2017). Phenolic content and antioxidant activity of pearled wheat and roller-milled fractions. LWT-Food Science and Technology 78:151-159.

Bhattacharyya P, Kumaria S, Job N, Tandon P (2015a). Phytomolecular profiling and assessment of antioxidant activity within micropropagated plants of Dendrobium thyrsiflorum: A threatened, medicinal orchid. Plant Cell Tissue and Organ Culture 122:535550.

Bhattacharyya P, Kumaria S, Tandon P (2015b). Applicability of ISSR and DAMD markers for phyto-molecular characterization and association with some important biochemical traits of Dendrobium nobile, an endangered medicinal orchid. Phytochemistry 117:306-316. 
464

Bhattacharyya P, Kumaria S, Tandon P (2016). High frequency regeneration protocol for Dendrobium nobile: A model tissue culture approach for propagation of medicinally important orchid species. South Africa Journal of Botany 104:232-243.

Brewer M (2011). Natural antioxidants: Sources, compounds, mechanisms of action, and potential applications. Comprehensive Reviews in Food Science and Food Safety 10:221-247.

Bulpitt C (2005). The uses and misuses of orchids in medicine. QJM: An International Journal of Medicine 98:625-631.

Caleja C, Barros L, Antonio AL, Oliveira MBP, Ferreira IC (2017). A comparative study between natural and synthetic antioxidants: Evaluation of their performance after incorporation into biscuits. Food Chemistry 216:342-346.

Chao PY, Lin SY, Lin KH, Liu YF, Hsu JI, Yang CM, Lai JY (2014). Antioxidant activity in extracts of 27 indigenous Taiwanese vegetables. Nutrients 6:2115-2130.

Chen C (2015). Application of growth models to evaluate the microenvironmental conditions using tissue culture plantlets of Phalaenopsis Sogo Yukidian 'V3'. Scientia Horticulturae 191:25-30.

Chen CL, Tsai WH, Chen CJ, Pan TM (2016). Centella asiatica extract protects against amyloid $\beta_{140}$-induced neurotoxicity in neuronal cells by activating the antioxidative defence system. Journal of Traditional Complementary Medicine 6:362-369.

Chinsamy M, Finnie J, Van Staden J (2014). Anti-inflammatory, antioxidant, anti-cholinesterase activity and mutagenicity of South African medicinal orchids. South Africa Journal of Botany 91:8898.

de la Rosa-Manzano E, Andrade JL, García-Mendoza E, Zotz G, ReyesGarcía C (2015). Photoprotection related to xanthophyll cycle pigments in epiphytic orchids acclimated at different light microenvironments in two tropical dry forests of the Yucatan Peninsula, Mexico. Planta 242:1425-1438.

Dinis TC, Madeira VM, Almeida LM (1994). Action of phenolic derivatives (acetaminophen, salicylate, and 5-aminosalicylate) as inhibitors of membrane lipid peroxidation and as peroxyl radical scavengers. Archives of Biochemistry and Biophysics 315:161-169.

Djeridane A, Yousfi M, Nadjemi B, Boutassouna D, Stocker P, Vidal N (2006). Antioxidant activity of some Algerian medicinal plants extracts containing phenolic compounds. Food Chemistry 97:654 660.

Giri L, Dhyani P, Rawat S, Bhatt ID, Nandi SK, Rawal RS, Pande V (2012). In vitro production of phenolic compounds and antioxidant activity in callus suspension cultures of Habenaria edgeworthii: A rare Himalayan medicinal orchid. Industrial Crops Production 39:1-6.

Guo WJ, Lin YZ, Lee N (2012). Photosynthetic light requirements and effects of low irradiance and daylength on Phalaenopsis amabilis. Journal of American Society of Horticulture Science 137:465-472.

He X, Fang J, Wang X, Zhao Z, Chang Y, Guo H, Huang L (2016). Bletilla striata: Medicinal uses, phytochemistry and pharmacological activities. Journal of Ethnopharmacology 195:20-38.

Hsing HX, Lin YJ, Tong CG, Li MJ, Chen YJ, Ko SS (2016). Efficient and heritable transformation of Phalaenopsis orchids. Botanical
Study 57:30.

Huang MY, Lin KH, Lu CC, Chen LR, Hsiung TC, Chang WT (2017). The intensity of blue light-emitting diodes influences the antioxidant properties and sugar content of oyster mushrooms (Lentinussajor-caju). Scientia Horticulturae 218:8-13.

Huang SS, Su SY, Chang JS, Lin HJ, Wu WT, Deng JS, Huang GJ (2016). Antioxidants, anti-inflammatory, and antidiabetic effects of the aqueous extracts from Glycine species and its bioactive compounds. Botanical Study 57:38.

Huang YC, Chang YH, Shao YY (2006). Effects of genotype and treatment on the antioxidant activity of sweet potato in Taiwan. Food Chemistry 98:529-538.

Hübner A, Neto A, Sobreira F, Pinto C, Dario M, Lourenço F, Baby A, Bacchi E (2016). Phytochemistry, antioxidant activity, and sunscreen efficacy of hydroethanolic extract of Cabernet Sauvignon grape pomace (Vitis vinifera L.). Planta Medicine 81:227.

Ledford H, Niyogi K (2005). Singlet oxygen and photo-oxidative stress management in plants and algae. Plant Cell Environment 28:10371045.

Mancinelli AL, Yang CPH, Lindquist P, Anderson O, Rabino I (1975). Photocontrol of anthocyanin synthesis III. The action of streptomycin on the synthesis of chlorophyll and anthocyanin. Plant Physiology 55:251-257.

Pant B (2013). Medicinal orchids and their uses: Tissue culture a potential alternative for conservation. Africa Journal of Plant Science 7:448-467.

Pokorný J (2007). Are natural antioxidants better-and safer-than synthetic antioxidants? European Journal of Lipid Science Technology 109:629-642.

Porra R, Thompson W, Kriedemann P (1989). Determination of accurate extinction coefficients and simultaneous equations for assaying chlorophylls a and $\mathrm{b}$ extracted with four different solvents: Verification of the concentration of chlorophyll standards by atomic absorption spectroscopy. Biochim Biophys Acta-Bioenergetics 975:384-394.

Prasad KN, Yang B, Shi J, Yu C, Zhao M, Xue S, Jiang Y (2010). Enhanced antioxidant and antityrosinase activities of longan fruit pericarp by ultra-high-pressure-assisted extraction. Journal of Pharmaceutical and Biomedical Analysis 51:471-477.

Prasad KN, Yang B, Yang S, Chen Y, Zhao M, Ashraf M, Jiang Y (2009). Identification of phenolic compounds and appraisal of antioxidant and antityrosinase activities from litchi (Litchi sinensis Sonn.) seeds. Food Chemistry 116:1-7.

Pulido R, Bravo L, Calixto FS (2000). Antioxidant activity of dietary polyphenolsas determined by a modified ferric reducing / antioxidant power assay. Journal of Agricultural Food Chemistry 48:3396-3402.

Rashmi K, Shweta S, Sudeshna C, Vrushala P, Kekuda TP, Raghavendra H (2015). Antibacterial and radical scavenging activity of selected orchids of Karnataka, India. Science, Technology and Arts Research Journal 4:160-164.

Rumbaoa RG, Cornago DF, Geronimo IM (2009). Phenolic content and antioxidant capacity of Philippine sweet potato (Ipomoea 
batatas) varieties. Food Chemistry 113:1133-1138.

Schuster R, Zeindl L, Holzer W, Khumpirapang N, Okonogi S, Viernstein H, Mueller M (2017). Eulophia macrobulbon - an orchid with significant anti-inflammatory and antioxidant effect and anticancerogenic potential exerted by its root extract. Phytomedicine 24:157-165.

Sikora E, Cieślik E, Leszczyńska T, Filipiak-Florkiewicz A, Pisulewski PM (2008). The antioxidant activity of selected cruciferous vegetables subjected to aquathermal processing. Food Chemistry 107:55-59.

Štajner D, Popović BM, Kapor A, Boža P, Štajner M (2010). Antioxidant and scavenging capacity of Anacamptis pyrimidalis L. pyrimidal orchid from Vojvodina. Phytotherapy Research 24:759763.

Sun A, Liu J, Pang S, Lin J, Xu R (2016). Two novel phenanthraquinones with anti-cancer activity isolated from Bletilla striata. Bioorganic \& Medicinal Chemistry Letters 26:2375-2379.
Takahashi S, Badger M (2011). Photoprotection in plants: a new light on photosystem II damage. Trends in Plant Science 16:53-60.

Tatsuzawa F, Ichihara K, Shinoda K, Miyoshi K (2010). Flower colours and pigments in Disa hybrid (Orchidaceae). South African Journal of Botany 76:49-53.

Tsai CC, Chou CH, Wang HV, Ko YZ, Chiang TY, Chiang YC (2015). Biogeography of the Phalaenopsis amabilis species complex inferred from nuclear and plastid DNAs. BMC Plant Biology 15:202.

Yoshiki Y, Kahara T, Okubo K, Sakabe T, Yamasaki T (2001). Superoxide-and 1, 1-diphenyl-2-picrylhydrazyl radical-scavenging activities of soyasaponin $\beta \mathrm{g}$ related to gallic acid. Bioscience, Biotechnology, and Biochemistry 65:2162-2165.

Zahara M, Datta A, Boonkorkaew P (2016). Effects of sucrose, carrot juice and culture media on growth and net $\mathrm{CO}_{2}$ exchange rate in Phalaenopsis hybrid 'Pink'. Scientia Horticulturae 205:17-24. 